\title{
Fillet of pinna flap in scalp reconstruction
}

\author{
Luigi Esposito, Mariagrazia Moio, llaria Mataro, Bianca Aceto, Elena Ambrosino, Sergio Razzano, \\ Fabrizio Schonauer ${ }^{*}$
}

From 26th National Congress of the Italian Society of Geriatric Surgery

Naples, Italy. 19-22 June 2013

\section{Introduction}

Fillet flaps are commonly used to cover skin defects after trauma or tumors, especially in the extremities [1-5].

\section{Methods}

We report four patients operated in the last three years, for lesions of the ear, invading the post auricular skin and infiltrating into the scalp.

On examination these ulcerating lesions had the clinical appearance of deeply infiltrating basal cell carcinoma. Surgery was performed under general anaesthesia.

After resection was performed with $1 \mathrm{~cm}$ skin margins, down and including the temporal fascia, the clear anterior skin surface of the upper pole of the ear was freed by its internal cartilaginous skeleton. The obtained fillet flap of the homolateral upper ear pole was raised and reflected posteriorly to cover the wound completely or partially. When needed, a split skin graft was added to the reconstruction.

\section{Results}

Histology gave the confirmation of the diagnosis and indications on the radicality in the operated patients. The cosmetic result was satisfactory. Follow up at a mean 6 months showed no recurrence.

\section{Conclusions}

Several possibilities for the coverage of scalp defects have been reported[6], including local or pedicled flaps.

We describe the use of fillet of pinna flap to cover periauricular scalp defects. We are not aware of any report of this type of flap to cover defects following tumour resection.

The main advantages of the fillet of pinna flap are its durable coverage, colour match of the skin and absence of a donor site defect. In our patients, flaps were

\footnotetext{
* Correspondence: fschona@libero.it

Plastic Surgery Unit, University Federico II - Via Sergio Pansini 5, Naples, Italy
}

composed of healthy tissue which otherwise would have been discarded in the resection. In our opinion, fillet of pinna flaps can be used to cover the periauricular scalp defects when the auricular skin is clear and not been invaded by the lesion.

Published: 16 September 2013

\section{References}

1. Al-Qattan MM: Lenghtening of the finger fillet flap to cover dorsal wrist defects. J Hand Surg 1997, 22:550-1.

2. Cave EF, Rowe CR: Utilization of skin from deformed and useless finger to cover defects in the hand. Ann Surg 1947, 125:126-7.

3. Chase AR: The damaged index digit. J Bone Joint Surg 1968, 50:1152-60.

4. Goitz RJ, Westkaemper JG, Tomaino MM, Sotereanos DG: Soft tissue defects of the digits. Hand Clinics 1997, 13:189-204.

5. Schonauer F, Schaden L, Teo TC: Fillet of finger flap for hand resurfacing after tumor excision. European Journal of Surgical Oncology 1999, 25:424-426.

6. De Haro F, Giraldo F: Bipedicled fronto-occipital flap for reconstruction of postoncologic defects of the lateral scalp. Plast Reconstr Surg 2001, 107(2):506-10.

doi:10.1186/1471-2482-13-S1-A45

Cite this article as: Esposito et al:: Fillet of pinna flap in scalp reconstruction. BMC Surgery 2013 13(Suppl 1):A45.
Submit your next manuscript to BioMed Central and take full advantage of:

- Convenient online submission

- Thorough peer review

- No space constraints or color figure charges

- Immediate publication on acceptance

- Inclusion in PubMed, CAS, Scopus and Google Scholar

- Research which is freely available for redistribution
() Biomed Central

\section{() Biomed Central}

